setting need not necessarily produce a permanent change in the natural history of the disorder, however, but may simply be an effect that requires more than 16 weeks to disappear. The most likely explanation, however, of the failure of blood pressure to return to pretreatment levels is that the diuretic therapy, which was kept constant throughout the trial, continued to exert a mild hypotensive effect.

It is also seen that in the group of patients who on entry to the trial continued taking propranolol there was a significant fall both in systolic $(P<0.05)$ and diastolic $(P<0.01)$ blood pressures, in spite of an unaltered dose for a mean period of 21.9 months. Over the first period of the trial the fall in diastolic pressure on propranolol was about $2 \mathrm{~mm}$. $\mathrm{Hg} /$ month. This effect is probably due to the increased attention inevitably received by patients during any clinical trial.

The results in Fig. 2 show the reduction of heart rate commonly associated with propranolol. It was not possible, however, to use the pulse rate as a clinical guide to the fall in blood pressure that was seen in these patients.

There was no clinical evidence of postural or exercise hypotension in propranolol-treated patients, and blood pressure measurements confirmed the lack of postural hypotension. There was, however, a small rise in systolic pressure of about $3.6 \mathrm{~mm}$. $\mathrm{Hg}$, and a small fall in diastolic pressure of about 5.7 $\mathrm{mm}$. $\mathrm{Hg}$, occurring on exercise in patients on propranolol. Although these were clinically small changes, statistical analysis showed the diastolic falls to be significant at the $1 \%$ level in both sequence groups, and the systolic rise to be significant (also at $1 \%$ ) but only in the propranolol-placebo sequence group.

We wish to thank Imperial Chemical Industries Ltd. (Pharmaceuticals Division) for the supply of propranolol and placebo tablets. We are indebted to the medical and statistical staff of the Clinical Research Department, Alderley Park, for their assistance in the preparation of this paper, and to the nursing staff of the hypertension unit and the pharmaceutical department of Clatterbridge Hospital for their co-operation throughout the trial.

\section{REFERENCES}

Frohlich, E. D., Tazari, R. C., Dustan, H. P., and Page, I. H. (1968) Circulation, 37, 417

Gebhardt, W., et al. (1967). Wiener Klinische Wochenschrift, 79, 337. Humphreys, G. S., and Delvin, D. G. (1968). British Medical fournal, 2, 601.

Paterson, J. W., and Dollery, C. T. (1966). Lancet, 2, 1148.

Prichard, B. N. C. (1964). British Medical fournal, 1, 1227.

Prichard, B. N. C., and Gillam, P. M. S. (1966). American fournal of Cardiology, 18, 387.

Prichard, B. N. C., and Gillam, P. M. S. (1969). British Medical fournal, 1, 7 .

Richardson, D. W., Freund, J., Gear, A. S., Mauck, H. P., jun., and Preston, L. W.'(1967). Circulation, 37, 534.

Richards, F. A. (1966). American fournal of Cardiology, 18, 384.

Tewari, S. N., and Grant, R. H. E. (1968). Postgraduate Medical fournal, 44, 509.

Waal, H. J. (1966). Clinical Pharmacology and Therapeutics, 7, 588.

\title{
Hypotension Caused by L-Dopa
}

\section{B. CALNE, ${ }^{*}$ D.M., M.R.C.P. ; JENNIFER BRENNAN, $\dagger$ B.SC., M.SC. ; A. S. D. SPIERS, ${ }^{*}$ PH.D., M.R.A.C.P.} G. M. STERN, $\ddagger$ M.D., M.R.C.P.

\begin{abstract}
Summary: In 20 patients with idiopathic Parkin$S$ sonism maximum tolerated doses of $L$-dopa were found to induce a mean reduction in blood pressure (erect systolic) of $19.3 \mathrm{~mm} . \mathrm{Hg}$, without any significant change in pulse rate. This hypotension may be due to dopamine, acting on adrenergic nerve endings or on the central nervous system itself.
\end{abstract}

\section{Introduction}

It has been reported that both hypertension and hypotension may occur in patients undergoing treatment with L-dopa for Parkinsonism (Cotzias et al., 1968; 1969; Yahr et al., 1968; Calne et al., 1969; Duvoisin et al., 1969; Godwin-Austen et al., 1969). Details of the extent of blood pressure changes have not been previously reported.

\section{Methods}

We have studied the blood pressure and pulse rate in 20 idiopathic Parkinsonian patients who had been receiving maximum tolerated dosage of oral L-dopa for a minimum of six weeks. We repeated the observations six weeks after

* Research Fellow, University College Hospital, London W.C.1. Present address: Hammersmith Hospital, Ducane Road, London W.12. † Student, Department of Medical Statistics and Epidemiology, London School of Hygiene and Tropical Medicine, London W.C.1. ¥ Consultant Neurologist, University College Hospital, London W.C.1. switching to inert tablets. Patients were unaware of the change to placebo unless decoding occurred as a result of the substantial clinical deterioration which of ten too's place when Ldopa was stopped. The blood pressure was measured with a standard sphygmomanometer and the pulse by palpation of the radial artery.

The patient lay down on a couch, and the blood pressure and pulse rate were immediately recorded. Observations were repeated after the patient had been supine for three minutes and again one minute after standing erect. The initial measurements on lying down were discarded (they were carried out only as a conditioning manoeuvre to accustom patients to the recording situation). Statistical analyses were performed on the observations made three minutes after lying down and one minute after standing. These are referred to as the "supine" values and "erect" values. The mean dose of L-dopa was 3 g. per day (range 1-8 g.).

\section{Results}

The results are shown in the Table of mean values. Paired sample $t$ tests were used to establish the significance levels of the differences. It is evident that L-dopa lowered both the systolic and the diastolic blood pressure in the erect and supine positions. In addition, it augmented the postural drop in both systolic and diastolic pressures. No significant change in pulse rate was induced by L-dopa. In $75 \%$ of the patients the 
systolic blood pressure was lowered by at least $10 \mathrm{~mm} . \mathrm{Hg}$, and in $35 \%$ by at least $30 \mathrm{~mm} . \mathrm{Hg}$.

Mean Values of Blood Pressure and Pulse Rate

\begin{tabular}{|c|c|c|c|c|c|}
\hline & & & Drug & Placebo & Difference \\
\hline \multicolumn{6}{|c|}{ Systolic Blood Pressure (mm. $\mathrm{Hg}$ ) } \\
\hline $\begin{array}{l}\text { Erect } \\
\text { Lying } \quad \ldots \\
\text { Difference }\end{array}$ & $\begin{array}{l}\cdots \\
\cdots\end{array}$ & $\begin{array}{l}. \\
\cdots \\
\cdots\end{array}$ & $\begin{array}{c}114.4 \\
133.8 \\
-19.4 \dagger\end{array}$ & $\begin{array}{c}133.7 \\
144 \cdot 4 \\
-10 \cdot 8 t\end{array}$ & $\begin{array}{r}-19 \cdot 3 \dagger \\
-10.7 * \\
8.7 \dagger\end{array}$ \\
\hline \multicolumn{6}{|c|}{ Diastolic Blood Pressure (mm. $\mathrm{Hg}$ ) } \\
\hline $\begin{array}{l}\text { Erect } \quad \ldots \\
\text { Lying } \quad \ldots \\
\text { Difference }\end{array}$ & $\begin{array}{l}\ldots \\
\cdots\end{array}$ & $\begin{array}{l}\ldots \\
\ldots \\
.\end{array}$ & $\begin{array}{l}79 \cdot 8 \\
86 \cdot 2 \\
-6 \cdot 4 \dagger\end{array}$ & $\begin{array}{r}89.5 \\
91.4 \\
-2.0\end{array}$ & $\begin{array}{r}-9 \cdot 7 t \\
-5 \cdot 3 * \\
4 \cdot 4 t\end{array}$ \\
\hline \multicolumn{6}{|c|}{ Pulse Rate (beats/min.) } \\
\hline $\begin{array}{l}\text { Erect } \quad \ldots \\
\text { Lying } \quad \ldots \\
\text { Difference }\end{array}$ & $\begin{array}{l}\ldots \\
\cdots\end{array}$ & $\begin{array}{l}\cdots \\
\therefore \\
\therefore\end{array}$ & $\begin{array}{c}90 \cdot 1 \\
81 \cdot 3 \\
8 \cdot 8+\end{array}$ & $\begin{array}{c}88 \cdot 7 \\
80 \cdot 9 \\
7 \cdot 8+\end{array}$ & $\begin{array}{l}1.4 \\
0.4 \\
1.0\end{array}$ \\
\hline
\end{tabular}

*Significant at $5 \%$ level. +Significant at $1 \%$ level.

\section{Discussion}

These results show that L-dopa has a significant hypotensive action in man. As L-dopa is a precursor of noradrenaline this observation is somewhat paradoxical. Studies on the metabolites of catecholamines excreted by patients receiving L-dopa indicate that there are very large increases in dopamine turnover, and only relatively small increases in noradrenaline metabolism. It is possible that dopamine is responsible for the hypotension. Dopamine can release noradrenaline from adrenergic nerve endings to give a sympathomimetic effect (Spiers and Calne, 1969), which may be followed by depletion of noradrenaline stores in spite of the fact that dopamine is the immediate precursor of noradrenaline (Harrison et al., 1963; Eränko and Räisänen, 1966).

It has also been shown (Collins and West, 1968) that Ldopa can be taken up into sympathetic nerve endings in the rabbit, after which the arrival of a nerve impulse leads to the release of dopamine in addition to noradrenaline. J. H. Burn (personal communication, 1969) suggested that the "dilution" of noradrenaline in this way may be responsible for the hypotension in Parkinsonian patients receiving large doses of L-dopa, because the direct action of dopamine on receptors in the blood vessels varies according to site and species from weak vasoconstriction to vasodilatation (Burn and Rand, 1958;
Goldberg and Sjoerdsma, 1959; Goldberg et al., 1969). A further possibility is that dopamine may be exerting a more complex action in the central nervous system, or L-dopa itself may possess relevant central or peripheral pharmacological activity.

Patients with Parkinsonism often display autonomic disturbances such as excessive sweating and constipation. The cardiovascular reflexes may occasionally be severely impaired (Shy and Drager, 1960; Barbeau et al., 1969). Our results in patients on placebo for six weeks show slight orthostatic hypotension, which is probably consequent on their Parkinsonism, though it might alternatively represent some persisting activity of L-dopa.

We wish to thank the Wellcome Foundation for a generous supply of L-dopa. We are grateful to Professor D. R. Laurence and Dr. C. J. Dickinson for helpful discussion. One of us (D.B.C.) is a Wellcome Fellow in Clinical Pharmacology and one (A.S.D.S.) a Nuffield Research Fellow.

\section{REFERENCES}

Barbeau, A., Gillo-Jeffroy, L., Boucher, R., Nowaczynski, W., and Genest, J. (1969). Science, 165, 291.

Burn, J. H., and Rand, M. J. (1958). Fournal of Physiology, 144, 314.

Calne, D. B., Stern, G. M., Laurence, D. R., Sharkey J., and Armitage, P. (1969). Lancet, 1, 744 .

Collins, G. G. S., and West, G. B. (1968). British fournal of Pharmacology, 34, 514.

Cotzias, G. C., Papavasiliou, P. S., Gellene, R., and Aronson, R. B. (1968). Transactions of the Association of American Physicians, 81, 171 .

Cotzias, G. C., Papavasiliou, P. S., Gellene, R., Aronson, R. B., and Mena, I. (1969). In Parkinsonism and Parkinsonian Syndrome, edited by F. J. Gillingham and I. M. L. Donaldson, p. 185 Edinburgh, Livingstone.

Duvoisin, R., Schear, M., Hoehn, M. M., and Yahr, M. (1969). In Parkinsonism and Parkinsonian Syndrome, edited by F. J. Gilling ham and I. M L. Donaldson, p. 185. Edinburgh, Livingstone.

Eränko, O., and Räisänen, L. (1966). In Mechanisms of Release of Biogenic Amines, edited by U. S. Von Euler, S. Rosell, and B. Uvnäs, p. 73. Oxford, Pergamon.

Godwin-Austen, R. B., Tomlinson, E. B., Frears, C. C., and Kok, H. W. L. (1969). Lancet, 2, 212

Goldberg, L. I., and Sjoerdsma, A. (1959). Fournal of Pharmacology and Experimental Therapeutics, 127, 212.

Goldberg, L. I., Talley, R. C., and McNay, J. L. (1969). Progress in Cardiovascular Diseases, 12, 40.

Harrison, W. H., Levitt, M., and Udenfriend, S. (1963). Fournal of Pharmacology and Experimental Therapeutics, 142, 157.

Shy, G. M., and Drager, G. A. (1960). Archives of Neurology, 2, 511

Spiers, A. S. D., and Calne, D. B. (1969). British Medical fournal, 4 333.

Yahr, M. D., Duvoisin, R. C., Hoehn, M. M., Schear, M. J.. and Barrett, 93. E. (1968). Transactions of the American Neurological Association,

\section{Preliminary Communication}

\section{Respiratory Stimulants in Treatment of Perinatal Asphyxia}

British Medical fournal, 1970, 1, 475-477

Cummary: The effects of two analeptic drugs-taloxi$\checkmark$ mine and ethamivan-have been studied in asphyxiated fetal and newborn rabbits. In primary apnoea ethamivan reduced the time before the onset of gasping, while during gasping taloximine increased the gasp rate. In secondary apnoea neither drug initiated respiration, though most animals could be resuscitated by using intermittent positive pressure respiration. From these results it is suggested that analeptic drugs have no place in obstetric or neonatal departments.

\section{INTRODUCTION}

Despite theoretical, clinical, and experimental evidence that analeptics are of no benefit in neonatal asphyxia (Cross, 1968) a recent authoritative publication (Bound, 1969) recommends their use, and replies to a questionary which we circulated in August 1969 to the 32 approved London institutions of midwifery training showed that 12 out of the 23 that answered favoured the use of one or more of them.

It seems necessary to reiterate the sequence of events in the asphyxia of the newborn mammal, exemplified by asphyxia in nitrogen of the newborn rabbit which passes through the following stages: (a) a short period of hyperventilation, (b) primary apnoea lasting some 5 minutes, (c) a gasping phase lasting a further 15 minutes, and $(d)$ secondary apnoea lasting until death in the absence of effective intervention.

The behaviour of fetal monkeys, lambs, and rabbits is similar if useful respiratory exchange is prevented. It is clear also that 